\title{
Chest CT as a screening tool for COVID-19 in unrelated patients and asymptomatic subjects without contact history is unjustified
}

\author{
Wei-Hong Liu, Xia-Wu Wang, Zhong-Quan Cai, Xiao Wang, Xiao-Lu Huang, Zhi-Gang Jin \\ General Hospital of China Resources \& Wuhan Iron and Steel Corporation, Wuhan 430080, China \\ Correspondence to: Dr. Wei-Hong Liu. Department of Radiology, General Hospital of China Resources \& Wuhan Iron and Steel Corporation, Wuhan \\ 430080, China. Email: liuwhwygn@sina.com.
}

Submitted Mar 02, 2020. Accepted for publication Mar 26, 2020.

doi: 10.21037/qims.2020.04.02

View this article at: http://dx.doi.org/10.21037/qims.2020.04.02

The 2019 novel coronavirus disease (COVID-19) was firstly identified in Wuhan, Hubei Province, China. In China, the data on 29 Feb 2020 showed the fatality rate was $3.6 \%(2,835 / 79,251)$ with most deaths occurred in Wuhan. The fatality rate outside of Hubei province was $0.85 \%(111 / 13,052)$, with seven provinces/regions without death cases (1). According to recommendation, persons with contacts and suspicious exposure are advised to have a 14-day health observation period. Once they display any symptoms, they should seek medical attention immediately. Suspected cases are those with epidemiologic risk and with clinical features. Confirmed cases are diagnosed with pathogenic evidence.

Despite many literature reports on CT features of COVID-19, we argue the role of CT for COVID-19 patients' management remain poorly defined (2). Of note, the case report from USA used serial radiographs to monitor the lung infiltrates change over time (3), and the patient group in Germany did not report imaging test (4). In addition to the widespread application of chest CT for COVID-19 patients, recently a large proportion of hospitals outside Wuhan/Hubei in China use chest CT scan as a COVID-19 screening tool for all in-patients who are hospitalized with illnesses un-related to COVID-19, despite they don't have contact history or respiratory symptoms. In some places, chest CT is used as a COVID-19 screening tool for employees assuming work after the Spring Festival break. We estimate the volume of incurred chest CT scans will be in tens of millions.

Chest CT to screen COVID-19 may not be sensitive. Initial reports have been focused on severe patients and reported high chest CT positive rate. For milder cases, the chest CT positive rate will be much lower (5). To our knowledge, chest CT positive rate among asymptomatic COVID-19 patients remain unknown $(6,7)$. Moreover, a negative chest CT does not rule out this disease for COVID-19 patients during their contagious latency period. The burdens of CT include the CT procedure induced virus transmission as well as oncogenic radiation.

We advocate screening for COVID-19 should focus on the contact history, symptoms, pathogenic evidence, and early isolation for suspected cases. There is no scientific evidence to recommend the use of chest $\mathrm{CT}$ as a screening tool for asymptomatic subjects without contact history. Excessive CT scans in a large population may lead to substantial long-term burdens on the society.

\section{Acknowledgments}

Funding: None.

\section{Footnote}

Conflicts of Interest: All authors have completed the ICMJE uniform disclosure form (available at http://dx.doi. org/10.21037/qims.2020.04.02). The authors have no conflicts of interest to declare.

Open Access Statement: This is an Open Access article distributed in accordance with the Creative Commons Attribution-NonCommercial-NoDerivs 4.0 International License (CC BY-NC-ND 4.0), which permits the non- 
commercial replication and distribution of the article with the strict proviso that no changes or edits are made and the original work is properly cited (including links to both the formal publication through the relevant DOI and the license). See: https://creativecommons.org/licenses/by-nc-nd/4.0/.

\section{References}

1. Available online: http://fms.news.cn/swf/2020_sjxw/2_1_ xgyq/index.html. Accessed February 29, 2020.

2. Wang YXJ, Liu WH, Yang $M$, Chen $W$. The role of CT for Covid-19 patient's management remains poorly defined. Ann Transl Med 2020;8:145.

3. Holshue ML, DeBolt C, Lindquist S, Lofy KH, Wiesman J, Bruce H, Spitters C, Ericson K, Wilkerson S, Tural A, Diaz G, Cohn A, Fox L, Patel A, Gerber SI, Kim L, Tong S, Lu X, Lindstrom S, Pallansch MA, Weldon WC, Biggs HM, Uyeki TM, Pillai SK; Washington State 2019-nCoV Case Investigation Team. First Case of 2019 Novel Coronavirus in the United States. N Engl J Med 2020;382:929-36.

Cite this article as: Liu WH, Wang XW, Cai ZQ, Wang $\mathrm{X}$, Huang XL, Jin ZG. Chest CT as a screening tool for COVID-19 in unrelated patients and asymptomatic subjects without contact history is unjustified. Quant Imaging Med Surg 2020;10(4):876-877. doi: 10.21037/qims.2020.04.02
4. Rothe C, Schunk M, Sothmann P, Bretzel G, Froeschl G, Wallrauch C, Zimmer T, Thiel V, Janke C, Guggemos W, Seilmaier M, Drosten C, Vollmar P, Zwirglmaier K, Zange S, Wölfel R, Hoelscher M. Transmission of 2019-nCoV Infection from an Asymptomatic Contact in Germany. $\mathrm{N}$ Engl J Med 2020;382:970-1.

5. Xu R, Du M, Li L, Zhen Z, Wang H, Hu X. CT imaging of one extended family cluster of corona virus disease 2019 (COVID-19) including adolescent patients and "silent infection”. Quant Imaging Med Surg 2020;10:800-4.

6. Wáng YX. A call for caution in extrapolating chest CT sensitivity for COVID-19 derived from hospital data to patients among general population. Quant Imaging Med Surg 2020;10:798-9.

7. Bernheim A, Mei X, Huang M, Yang Y, Fayad ZA, Zhang N, Diao K, Lin B, Zhu X, Li K, Li S, Shan H, Jacobi A, Chung M. Chest CT Findings in Coronavirus Disease-19 (COVID-19): Relationship to Duration of Infection. Radiology 2020. [Epub ahead of print]. doi: 10.1148/ radiol.2020200463. 